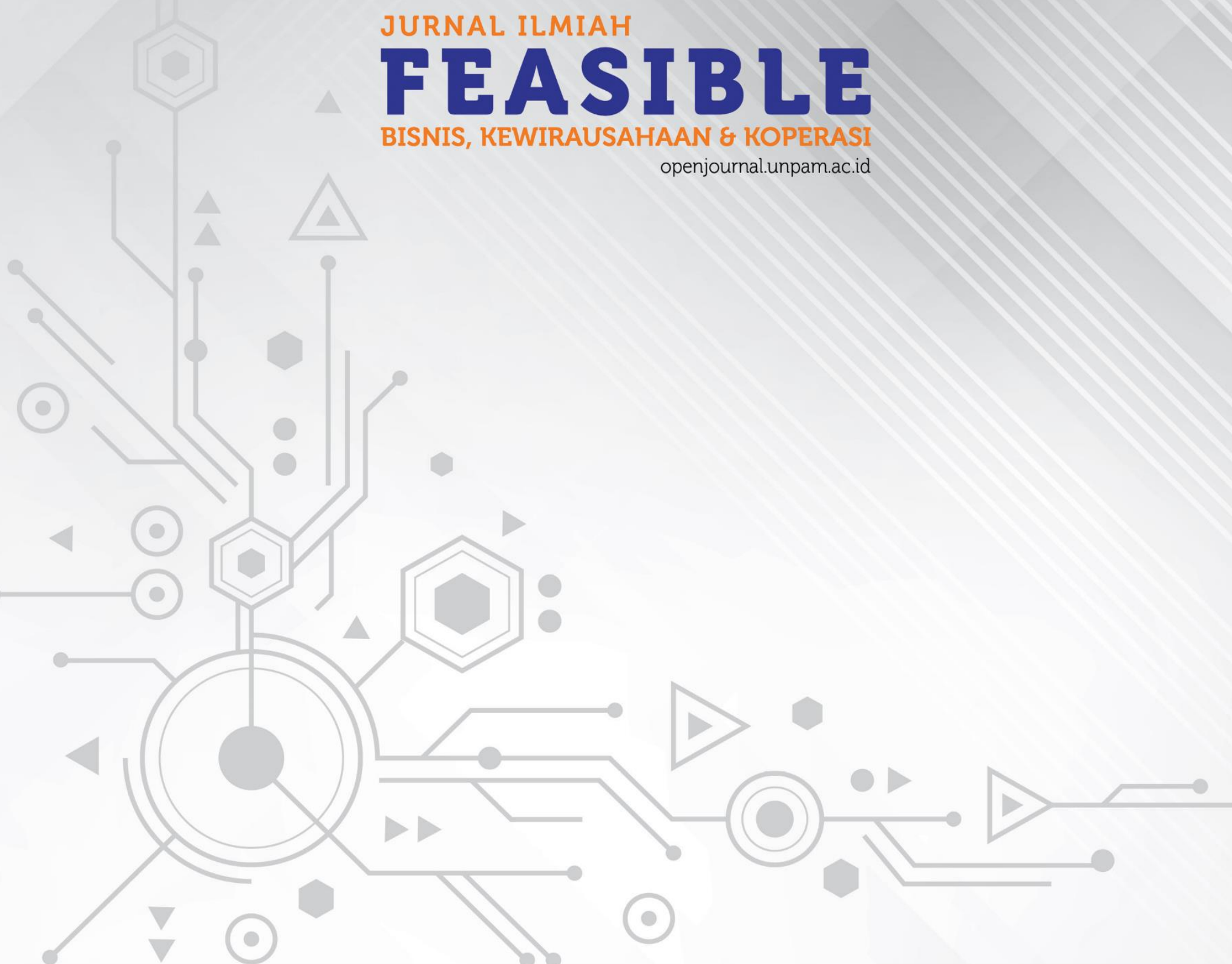




\title{
PENGARUH CAPITAL ADEQUACY RATIO DAN LOAN TO DEPOSIT RATIO TERHADAP RETURN ON ASSET PADA PT BANK UOB INDONESIA PERIODE 2009-2018
}

\author{
Dien Mardiana Yulianti \\ Fakultas Ekonomi, Universitas Pamulang \\ Diendiana1107@gmail.com
}

\begin{abstract}
Abstrak
Penelitian ini bertujuan untuk menganalisa pengaruh Capital Adequacy Ratio (CAR) dan Loan to Deposit Ratio (LDR) terhadap Return on Asset (ROA) pada PT Bank OUB Indonesia. Data yang digunakan dalam penelitian ini adalah bersumber dari data keuangan situs resmi Bank UOB Indonesia yang terdapat dalam laporan keuangan PT Bank UOB Indonesia. Sampel dari penelitian ini adalah data keuangan perusahaan PT Bank UOB Indonesia periode 2009-2018. Analisis data yang digunakan meliputi uji asumsi klasik, regresi linier berganda, uji koefisien determinasi, uji parsial dan uji simultan. Hasil uji parsial diperoleh CAR tidak berpengaruh signifikan terhadap ROA dan LDRberpengaruh signifikan terhadap ROA. Sedangkan hasil uji simultan CAR dan LDR berpengaruh tidak signifikan terhadap ROA dengan konstribusi sebesar $81 \%$.
\end{abstract}

Kata Kunci : Capital Adequacy Ratio, Loan to Deposit Ratio, Return on Asset.

\begin{abstract}
This study aims to analyze the effect of Capital Adequacy Ratio (CAR) and Loan to Deposit Ratio (LDR) on Return on Assets (ROA) at PT Bank OUB Indonesia. The data used in this study is sourced from financial data on the official website of Bank UOB Indonesia contained in the financial statements of PT Bank UOB Indonesia. The sample of this study is the financial data of PT Bank UOB Indonesia in the 2009-2018 period. Analysis of the data used includes the classical assumption test, multiple linear regression, coefficient of determination test, partial test and simultaneous test. Partial test results obtained by CAR do not have a significant effect on ROA and LDR have a significant effect on ROA. While the simultaneous test results of CAR and LDR have no significant effect on ROA with a contribution of $81 \%$.
\end{abstract}

Keywords : Capital Adequacy Ratio,Loan to Deposit Ratio, Return on Asset.

\section{PENDAHULUAN}

\section{Latar Belakang}

Perkembangan industri perbankan di Indonesia saat ini menunjukkan arah yang makin menyatu dengan ekonomi regional dan internasional yang dapat menunjang sekaligus dapat berdampak kurang menguntungkan. Sementara itu, 
perkembangan perekonomian nasional senantiasa bergerak cepat dengan tantangan yang semakin kompleks. Oleh karena itu, penyesuaian kebijakan di sektor perbankan dilakukan secara bertahap sesuai dengan kebutuhan dan kondisi perekonomian saat itu sehingga diharapkan dapat memperbaiki dan memperkukuh perekonomian nasional.

Bank adalah suatu bentuk usaha yang bergerak di bidang jasa dalam bidang keuangan yang memiliki peran dan fungsi penting dalam perekonomian dan pembangunan nasional. Fungsi utama perbankan Indonesia sebagaimana yang disyaratkan oleh Bank Indonesia. Bank adalah sebagai penghimpun dan penyalur dana masyarakat serta bertujuan untuk menunjang pelaksanaan pembangunan nasional dalam rangka meningkatkan pemerataan pembangunan dan hasilhasilnya, pertumbuhan ekonomi dan stabilitas nasional, ke arah peningkatan taraf hidup rakyat banyak dengan berpedoman pada prinsip kehati-hatian di setiap aktivitas yang dijalankannya. Dalam kegiatan usahanya mengandalkan kepercayaan masyarakat, maka bank harus mampu menunjukkan kredibiitasnya sehingga akan semakin banyak masyarakat yang bertransaksi di bank tersebut, salah satunya melalui peningkatan profitabilitas. Profitabilitas dapat dikatakan sabagai salah satu indikator yang paling tepat untuk menukur kinerja suatu perusahaan tersebut. Semakin tinggi profitabilitasnya, semakin baik pula kinerja keuangan perusahaan.

PT Bank UOB Indonesia adalah salah satu lembaga keuangan yang memperoleh pendapatan bunga dari debitur. Dengan adanya kegiatan bank berupa pemberian kredit, maka bank juga memasarkan produk-produk lainnya seperti Tabungan, Giro, Deposito dan lainnya. Bank UOB Indonesia dikenal sebagai bank yang memiliki fokus pada layanan kebutuhan usaha kecil menengah (UKM) dan basis nasabah ritel yang kuat. UOB Indonesia telah berhasil membangun bisnis konsumer maupun perbankan bagi perusahaan yang menawarkan produk-produk serta layanan treasury dan pengelolaan kas. Dengan jaringan layanan yang luas, sistem teknologi informasi yang memadai, struktur permodalan. UOB Indonesia mempunyai komitmen untuk menyediakan dukungan yang berarti bagi masyarakat dalam bidang seni, pendidikan dan anak-anak. Salah satunya adalah melalui kompetisi UOB Painting of the Year, lomba seni terlama di kawasan regional.

Beberapa faktor yang berpengaruh terhadap kinerja Bank UOB Indonesia adalah LDR dan ROA. Loan to Deposit Ratio (LDR) merupakan rasio yang digunakan untuk mengukur komposisi jumlah kredit yang di berikan dibandingkan dengan jumlah dana masyarakat dan modal sendiri yang di gunakan. (Kasmir, 2014), maka laba bank semakin meningkat (dengan asumsi Bank UOB Indonesia mampu menyalurkan kreditnya dengan efektif), dengan meningkatnya laba bank, 
maka kinerja bank juga meningkat. Dengan demikian besar kecilnya rasio LDR suatu bank akan mempengaruhi kinerja bank tersebut. Dalam penelitian ini, Return on Asset (ROA) digunakan sebagai ukuran kinerja perbankan, alasannya adalah karena ROA digunakan untuk mengukur kemampuan manajemen bank untuk memperoleh keuntungan (laba) secara keseluruhan. ROA merupakan rasio antara laba sebelum pajak terhadap total asset. Semakin besar ROA, menunjukkan kinerja keuangan yang semakin baik, karna tingakat kembalian (return) semakin besar. Apabila ROA meningkat, berarti profitabilitas perusahaan meningkat, sehingga dampak akhirnya adalah peningkatan profitabilitas yang dinikmati oleh pemegang saham

Berdasarkan permasalahan di atas penelitian dimaksudkan untuk mengetahui:

1. Pengaruh parsial Capital Adequacy Ratio terhadap Return on Asset pada PT Bank UOB Indonesia.

2. Pengaruh parsial Loan to Deposit Ratio terhadap Return on Asset PT Bank UOB Indonesia.

3. Pengaruh simultan Capital Adequacy Ratio dan Loan to Deposit Ratio terhadap Return on Asset pada PT Bank UOB Indonesia.

\section{METODE}

Penelitian ini menggunakan metode kuantitatif dengan eksplanasi deskriptif dimana dalam melakukan pembahasannya berdasarkan pendekatan angka yang kemudian dinarasikan secara factual. Lokasi penelitian ini beralamat di UOB Plaza Jl. M.H. Thamrin No. 10 Jakarta 10230 Indonesia data diampil dari Laporan Keuangan PT UOB Indonesia dengan mengakses situs resminya yaitu www.uob.co.id. Data kuantitatif yang dianalisa berupa laporan keuangan Bank UOB Indonesia periode 2009-2018.

\section{HASIL dan PEMBAHASAN}

\section{Hasil Penelitian}

Hasil penelitian berdasarkan data yang diperoleh dan diolah untuk masing-masing variable CAR, LDR dan ROA PT Bank UOB Indonesia, periode tahun 2009-2018 diuraikan sebagai berikut:

\begin{tabular}{|c|c|c|c|}
\hline \multicolumn{4}{|c|}{ Tabel 1.1. Laporan CAR, LDR dan ROA } \\
PT Bank UOB Indonesia \\
Periode 2oo9-2018 (dalam \%) \\
\begin{tabular}{|c|c|c|c|}
\hline Tahun & CAR & LDR & ROA \\
\hline 2009 & 27,65 & 93,50 & 2,84 \\
\hline 2010 & 25,08 & 95,68 & 3,01 \\
\hline 2011 & 19,81 & 90,59 & 1,95 \\
\hline 2012 & 19,84 & 95,57 & 2,51 \\
\hline 2013 & 17,39 & 90,56 & 2,16 \\
\hline 2014 & 16,56 & 88,29 & 1,16 \\
\hline 2015 & 15,67 & 93,97 & 0,74 \\
\hline 2016 & 15,86 & 88,62 & 0,71 \\
\hline 2017 & 16,25 & 82,61 & 0,32 \\
\hline 2018 & 15,01 & 93,52 & 0,69 \\
\hline
\end{tabular}
\end{tabular}

Sumber: $\underline{\text { www.uob.co.id }}$

Pembahasan penelitian pada masingmasing sampel variabel penelitian, pengujian, pemodelan, hasil dan interpretasi pengaruh variabel bebas (independent) terhadap variabel terikat (dependent) dan pengujian hipotesis dijelaskan sebagai berikut : 


\section{Uji Asumsi Klasik}

\section{Uji Normalitas}

Uji Normalitas merupakan hal yang penting karena dengan data tersebut dianggap dapat mewakili populasi. Pengujian normalitas data pada variabel CAR (X1), LDR (X2) dan ROA (Y), diperoleh hasil sebagai berikut:

Uji Normalitas dilakukan dengan 2 cara yaitu Uji Kolomogorov Smirnov Test dan Histogram Kurva Distribusi Normal. Uji Kolmogorov Smirnov Test untuk menguji apakah sebaran data berdistribusi normal. Adapun hasil pengujian Kolmogorov Smirnov Test disajikan pada hasil output SPSS 20 sebagai berikut:

Tabel 1.2. Uji Normalitas

One-Sample Kolmogorov-Smirnov Test

\begin{tabular}{ll|r|r|r|}
\hline & & \multicolumn{1}{c|}{ CAR } & \multicolumn{1}{c|}{ LDR } & \multicolumn{1}{c|}{ ROA } \\
\hline $\mathrm{N}$ & & 10 & 10 & 10 \\
Normal & Mean & .189120 & .912910 & .016090 \\
Parameters $^{\mathrm{a}, \mathrm{b}}$ & Std. & & & \\
Most & Deviation & .0429535 & .0404269 & .0099894 \\
Extreme & Absolute & .238 & .208 & .208 \\
Differences & Positive & .238 & .139 & .208 \\
Kolmogorov-Smirnov Z & -.182 & -.208 & -.134 \\
Asymp. Sig. (2-tailed) & .754 & .657 & .657 \\
a. Test distribution is Normal. \\
b. Calculated from data.
\end{tabular}

Berdasarkan hasil pengolahan dengan SPSS 20, terilhat bahwa Asymp.Sig (2tailed) pada masing-masing variable yaitu CAR sebesar 0,620, LDR sebesar 0,782, ROA sebesar 0,781. Semua variabel penelitian dapat dikatakan berdistribusi normal, karena Asymp.Sig (2-tailed) nya diatas 0,05. Kemudian dilakukan test Histogram Kurva Distribusi Normal. Terlihat bahwa data sudah berbentuk standar distribusi normal, yaitu sebaran data berbentuk lonceng terbalik.

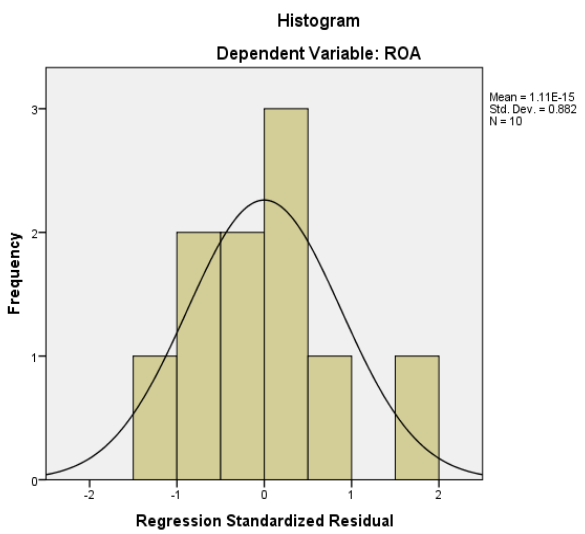

Gambar 1.1. Histogram (Data Asli)

Kemudian dilakukan pengujian Linearitas, untuk mengetahui apakah terdapat hubungan linear antara variabel independent dan dependent. Dari hasil pengolahan data maka diperoleh grafik Normal P-P Plot of Regression Strandarized Residual untuk Dependent Variable Laba Bersih.

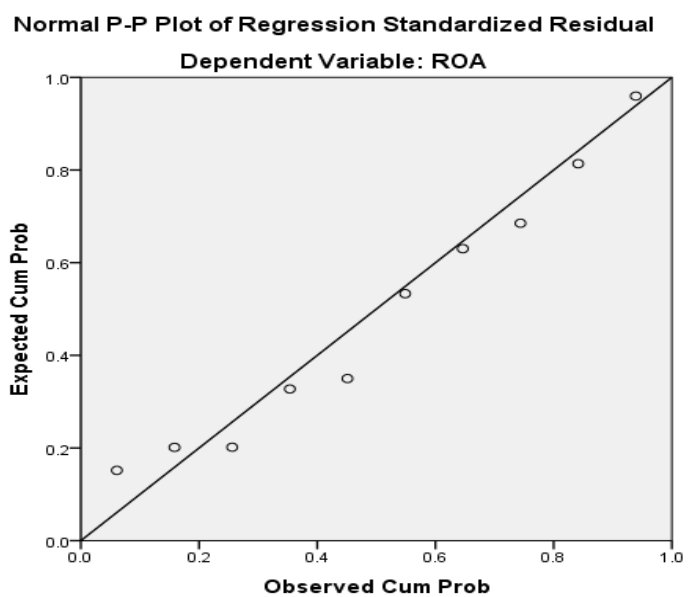

Grafik 1.2. Grafik Normal P-P Plot of Regression

Dari grafik di atas menunjukkan bahwa terdapat hubungan linear antara variabel independent dan dependent terlihat dari sebaran data mengikuti garis lurus dari kiri bawah ke kiri atas. 


\section{Uji Heteroskedastisitas}

Grafik dibawah ini menunjukkan adanya hubungan antara variabel independent dan dependent, dapat diketahui jika kita lihat data tersebar secara merata diatas dan dibawah garis nol, maka dengan demikian dapat disimpulkan bahwa tidak terjadi masalah heteroskedastisitas.
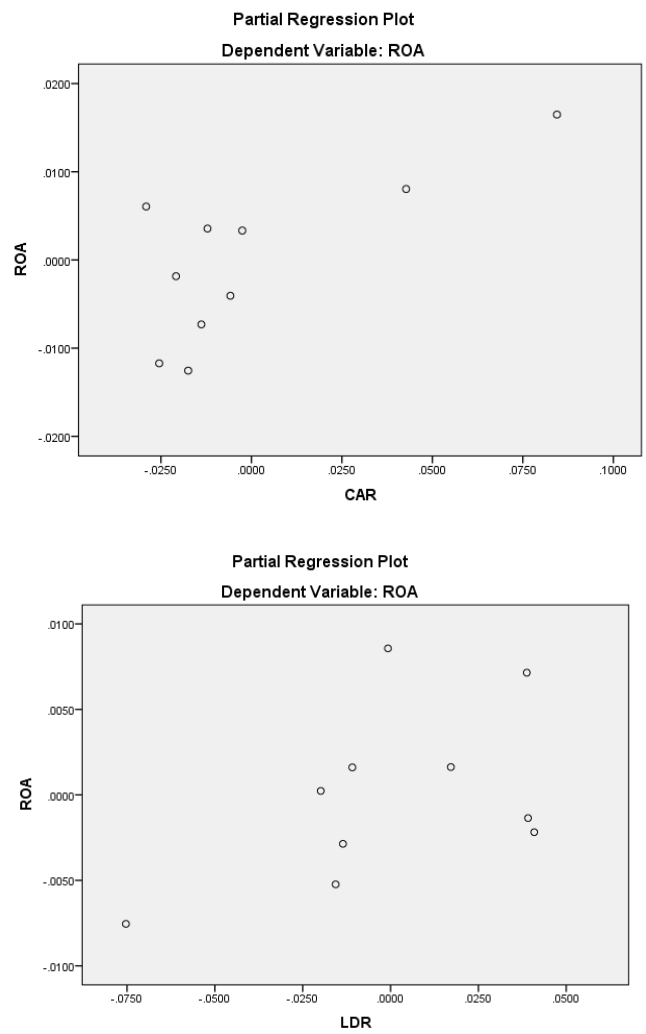

Gambar 1.3 Hasil Uji Heteroskendastisitas

\section{Uji Multikolinearitas}

Uji Multikolinearitas bertujuan untuk menguji apakah pada model regresi ditemukan adanya korelasi antara variabel independen. Model regresi yang baik seharusnya tidak korelasi diantara variabel independen. Dalam kebanyakan penelitian menyebutkan bahwa jika tolerance lebih dari 0,1 dan VIF kurang dari 10, maka tidak terjadi multikolineritas. Dalam penelitian ini uji multikolinearitas dapat dilihat pada tabel berikut:

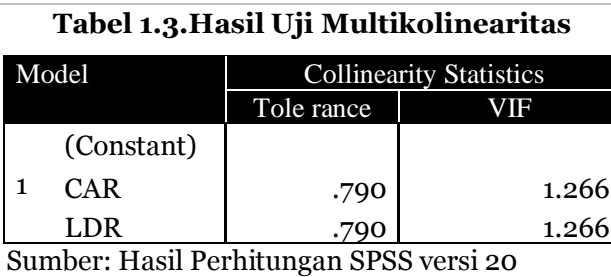

Pengujian yang dilakukan pada model regresi linier berganda, menunjukkan nilai tolerance masingmasing variabel CAR dan variabel $L D R$ sebesar 0.790. semua angka tersebut diatas 0,1. Pada kolom nilai VIF variabel CAR dan variabel LDR sebesar 1.266. Semua nilai VIF pada model regresi linier triple menunjukkan hasil VIF < 10, hal ini dapat dikatakan bahwa dalam penelitian ini tidak terjadi masalah Multikolinearitas.

\section{Uji Parsial (Uji t)}

Uji Parsial (Uji t) bertujuan untuk menguji pengaruh masing-masing variabel independen (X1) CAR dan (X2) LDR dan variabel dependen (Y) ROA. Berikut disajikan uji hipotesis menggunakan uji $t$ dengan pengujian Ho diterima bila Thitung < Ttabel, Ho ditolak bila Thitung $>$ Ttabel.

Hasil pengolahan data uji signifikansi parsial (uji t) dengan SPSS 20, terlihat pada tabel dibawah ini: 


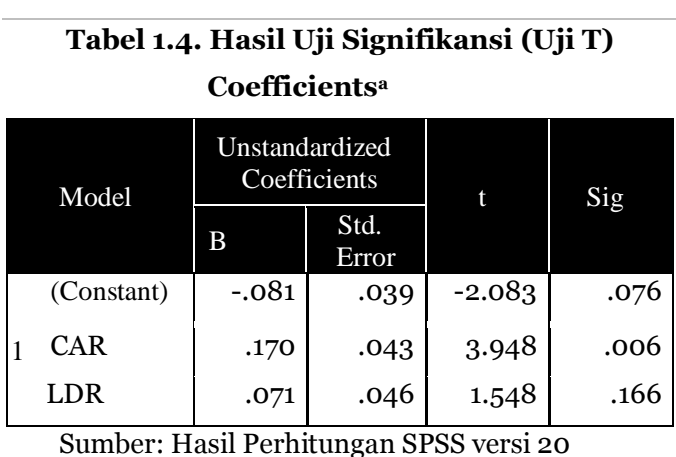

a. Hasil uji t variabel CAR terhadap variable $\mathrm{ROA}$ menunjukkan nilai $\mathrm{t}$ hitung 3.948 lebih besar dari t tabel 2.36462 dan dengan nilai signifikansi sebesar 0.006 di atas 0,05. Dengan demikian dapat disimpulkan bahwa secara parsial CAR tidak berpengaruh signifikan terhadap ROA.

b. Hasil uji t variabel LDR terhadap variable ROA menunjukkan nilai $t$ hitung 1,548 lebih kecil dari t tabel 2.36462 dan dengan nilai signifikansi sebesar 0.166 di atas 0,05. Dengan demikian dapat disimpulkan bahwa secara parsial LDR berpengaruh signifikan terhadap ROA.

\section{Uji Simultan (Uji F)}

Uji Simultan (Uji F) digunakan untuk menguji pengaruh variabel bebas CAR dan LDR secara bersama-sama terhadap variabel terikat (Y) ROA.

Berikut pengambilan keputusan menggunakan uji $\mathrm{t}$ dengan pengujian Ho diterima dan $\mathrm{Ha}$ ditolak bila Fhitung < Ftabel, Ho ditolak dan Ha diterima bila
Fhitung > Ftabel.

Hasilnya dapat dilihat pada tabel dibawah ini:

Tabel 1.5. Hasil Uji Simultan (Uji F)

\begin{tabular}{|c|c|c|c|c|c|}
\hline Model & $\begin{array}{l}\text { Sum of } \\
\text { Squares }\end{array}$ & df & $\begin{array}{l}\text { Mean } \\
\text { Square }\end{array}$ & $\mathrm{F}$ & Sig. \\
\hline Regression & .001 & 2 & .000 & 14.937 & $.003^{\mathrm{b}}$ \\
\hline 1 Residual & .000 & 7 & .000 & & \\
\hline Total & .001 & 9 & & & \\
\hline
\end{tabular}

a. Dependent Variable: ROA

b. Predictors: (Constant), LDR, CAR

Sumber: Hasil Perhitungan SPSS versi 20

Hasil uji F pengaruh variabel) CAR dan LDR secara bersama-sama terhadap variabel terikat ROA menunjukkan nilai F hitung 14.937 lebih besar dari F tabel 4.74 dengan nilai signifikansi $0.003<$ 0,05. Dengan demikian dapat disimpulkan bahwa secara bersamasama CAR dan LDR berpengaruh terhadap variabel terikat ROA.

\section{Uji Koefisien Determinasi}

Tabel 1.5. Hasil Koefisien Determinasi Model Summaryb

\begin{tabular}{l|c|c|c|r|r|}
\hline $\begin{array}{l}\text { Mo } \\
\text { del }\end{array}$ & $\mathrm{R}$ & $\begin{array}{c}\mathrm{R} \\
\text { Square }\end{array}$ & $\begin{array}{c}\text { Adjusted R } \\
\text { Square }\end{array}$ & $\begin{array}{c}\text { Std. Error } \\
\text { of the } \\
\text { Estimate }\end{array}$ & $\begin{array}{r}\text { Durbin- } \\
\text { Watson }\end{array}$ \\
\hline 1 & $.900^{\mathrm{a}}$ & .810 & .756 & .004935 & .904 \\
\hline
\end{tabular}
a. Predictors: (Constant), LDR, CAR
b. Dependent Variable: ROA
Sumber: Hasil Perhitungan SPSS versi 20

Uji koefisien determinasi dapat dilihat dari nilai $\mathrm{R}$ Square. Dari hasil pengolahan data menggunakan SPSS 20 dapat dilihat bahwa nilai R Square menunjukkan angka sebesar 0.810 yang berarti bahwa variabel CAR, LDR memberikan kontribusi yang sangat kuat terhadap Variabel ROA sebesar 81\% sedangkan sisanya sebesar $19 \%$ dikontribusi oleh Variabel lain diluar penelitian ini . 


\section{Analisis Regresi Linier Berganda}

Tabel 1.6. Hasil Analisis Regresi Linier Berganda Coefficients $^{\mathrm{a}}$

\begin{tabular}{|c|c|c|c|c|}
\hline \multirow{2}{*}{ Model } & \multicolumn{2}{|c|}{$\begin{array}{l}\text { Unstandardized } \\
\text { Coefficients }\end{array}$} & \multirow{2}{*}{$\mathrm{t}$} & \multirow{2}{*}{ Sig } \\
\hline & B & $\begin{array}{l}\text { Std. } \\
\text { Error }\end{array}$ & & \\
\hline (Constant) & -.081 & .039 & -2.083 & .076 \\
\hline $\begin{array}{l}1 \text { CAR } \\
\text { LDR }\end{array}$ & $\begin{array}{l}.170 \\
.071\end{array}$ & $\begin{array}{l}.043 \\
.046\end{array}$ & $\begin{array}{l}3.948 \\
1.548\end{array}$ & $\begin{array}{l}.006 \\
.166\end{array}$ \\
\hline
\end{tabular}

Dari output diatas, diperoleh nilai a sebesar -0.081, nilai CAR sebesar 0.170 dan nilai LDR sebesar 0.071. dengan demikian maka dapat dibentuk persamaan regresi linier berganda sebagai berikut::

$$
\mathrm{Y}=-0.081+0.170 \mathrm{X}_{1}+0.071 \mathrm{X}_{2}
$$

Berdasarkan model regrensi dan tabel di atas maka hasil regrensi linier berganda dapat dijelaskan sebagai berikut:

a. Nilai Constanta adalah -0.081 ini dapat diartikan jika CAR dan LDR bernilai o maka nilai ROA adalah 0.081 .

b. Nilai Koefisien Regresi CAR bernilai 0.170, hal ini dapat diartikan bahwa setiap peningkatan CAR sebesar satu satuan maka akan menaikkan ROA sebesar 0.170 satuan dengan asumsi variabel lainnya tidak dilakukan atau sama dengan 0.

c. Nilai Koefisien Regresi LDR bernilai 0.071 hal ini dapat diartikan bahwa setiap peningkatan LDR sebesar satu satuan maka akan menaikkan ROA sebesar 0.071 satuan dengan asumsi variabel lainnya tidak dilakukan atau sama dengan 0.

\section{Pembahasan}

4. Hasil uji parsial pengaruh Capital Adequacy Ratio terhadap Return on Asset diperoleh nilai thitung $=3.948>$ dari $t_{\text {tabel }}$ (2.3646) dengan nilai signifikansi sebesar 0.006. Artinya secara parsial Capital Adequacy Ratio berpengaruh signifikan terhadap Return on Asset.

5. Hasil uji parsial pengaruh Loan to Deposit Ratio terhadap Return on Asset diperoleh nilai $t_{\text {hitung }}(1.548)>$ dari $t_{\text {tabel }}$ (2.3646) dengan nilai signifikansi sebesar 0.166. Artinya secara parsial Loan to Deposit Ratio berpengaruh signifikan terhadap Return on Asset.

6. Hasil uji simultan Pengaruh Capital Adequacy Ratio dan Loan to Deposit Ratio terhadap Return on Asset pada PT Bank UOB Indonesia diperoleh nilai Fhitung $(14,937)$ lebih besar dari Ftabel $(4,74)$ dengan dengan nilai signifikan 0.003 artinya Capital Adequacy Ratio dan Loan to Deposit Ratio secara bersama-sama berpengaruh terhadap Return on Asset.

\section{SIMPULAN}

\section{Kesimpulan}

Berdasarkan hasil penelitian dan pembahasan yang telah diuraikan sebelumnya mengenai Capital Adequcy Ratio dan Loan to Deposit Ratio terhadap Return on Asset pada PT Bank UOB 
Indonesia periode 2009-2018, maka dapat diambil kesimpulan sebagai berikut:

1. Berdasarkan hasil uji parsial di atas dapat diketahui nilai $t_{\text {hitung }}$ dari variabel Capital Adequacy Ratio adalah 3.948 lebih besar dari t tabel 2.36462 dengan nilai signifikansi sebesar 0.006 . Dengan demikian dapat disimpulkan bahwa secara parsial Capital Adequacy Ratio berpengaruh signifikan terhadap Return on Asset.

2. Berdasarkan hasil uji parsial diatas dapat diketahui nilai $t_{\text {hitung }}$ dari variabel Loan to Deposit Ratio adalah 1,548 lebih kecil dari t tabel 2.36462 dengan nilai signifikansi sebesar 0.166 di atas 0,05. Dengan demikian dapat disimpulkan bahwa secara parsial Loan to Deposit Ratio tidak berpengaruh signifikan terhadap Return on Asset.

3. Berdasarkan pengujian hipotesis secara simultan yang telah di analisis, nilai Fhitung adalah 14.937 lebih besar dari F tabel 4.74 dengan nilai signifikansi 0.003 di bawah 0,05. Dengan demikian dapat disimpulkan bahwa secara bersama-sama Capital Adequacy Ratio dan Loan to Deposit Ratio berpengaruh tidak signifikan terhadap Return on Asset.

\section{Saran}

1. Capital Adequacy Ratio berpengaruh signifikan terhadap Return on Asset. Hasil ini mengidentifikasi bahwa kecilnya Capital Adequacy Ratio berpengaruh dengan kecilnya keuntungan yang didapat dari bank tersebut. Sehingga diharapkanagar bank dapat meningkatkan Capital Adequacy Ratio untuk meningkatkan profitabilitasnya dalam kondisi permodalan seperti apapun agar bank dapat terus beroperasi dengan baik.

2. Loan to Deposit Ratio tidak berpengaruh signifikan terhadap Return on Asset. Hasil ini mengidentifikasi bahwa semakin besarnya kredit yang disalurkan bank kepada nasabah, maka laba yang didapatkan bank akan meningkat dan Return on Asset juga akan meningkat karenanya bank agar terus meningkatkan Loan to Deposit Ratio dari sisi profitabilitas dan pada tingkat yang terus baik dari sisi likuiditasnya.

3. Pihak bank meningkatkan Capital Adequacy Ratio yang dimiliki sesuai dengan standar yang ditentukan oleh Bank Indonesia, yaitu sebesar 8\%. Serta menjaga kestabilan Loan to Deposit Ratio sesuai dengan ketentuan Bank Indonesia, yaitu sebesar 78\%-100\%. Karena akan memiliki dampak bagi peningkatan profitabilitas bank. Karena kedua variabel tersebut memiliki hubungan terhadap Return on Asset.

\section{DAFTAR PUSTAKA}

A A Yogi Prasanjaya dan I Wayan Ramantha. "Analisis Pengaruh Rasio CAR, BOPO, LDR dan Ukuran Perusahaan Terhadap Profitabilitas Bank Yang Terdaftar Di BEI”. Universitas Udayana, Bali, 
2013.

Ahmad Buyung Nusantara. "Analisis Pengaruh NPL. CAR, LDR dan BOPO Terhadap Profitabilitas Bank". Universitas Diponogoro, Semarang, 2009.

A Totok Budi Santoso, Sigit Triandari, Y. Sri Susilo. "Bank dan Lembaga Keuangan Lainnya". Salemba Empat, Jakarta, 2000.

Damayanti. Pipik dan Dhian Andanarini Minar Savitri. "Anlalisis Pengaruh Ukuran, CAR, Pertumbuhan Deposit, LDR Terhadap Profitabilitas Perbankan Go Public Di Indonesia Tahun 2005-2009”. STIE Totalwin, Semarang, 2012.

Delsy Setiawan Ratu Edo dan Ni Luh Putu Wiagustina. "Pengaruh Pihak Ketiga, NPL dan CAR Terhadap LDR dan ROA Pada Sektor Perbankan Di Bursa Efek Indonesia”. Univesitas Udayana, Bali, 2014.

Dendawijaya. Lukman. "Manajemen Perbankan”. Edisi Kedua, Cetakan Kedua, Galia Indonesia, Jakarta, 2005.

"Manajemen Perbankan". Edisi Kedua, Galia Indonesia, Jakarta, 2009.

Fahmi. Irham. "Analisis Kinerja Keuangan”. Cetakan Kesatu, Alfabeta, Bandung, 2011.

Ghozali. Imam. "Aplikasi Analisis Multivariate Dengan Program SPSS”. Edisi 3, Universitas
Diponogoro, Semarang, 2005. "Manajemen Risiko Perbankan". Universitas Diponogoro, Semarang, 2007.

Harahap. Sofyan Syafri. "Analisis Kritis Laporan Keuangan”. Rajawali Pers, Jakarta, 2010.

Harianto. Syawal. "Rasio Keuangan dan Pengaruhnya Terhadap Profitabilitas Pada Bank Pembiayaan Rakyat Syariah Di Indonesia". Universitas Islam Negeri, Jakarta, 2017.

Hasibuan, Melayu S.P. "Manajemen Dasar, Pengertian dan Masalah”. PT Bumi Aksara, Jakarta, 2009.

Home, Wachowicz Jr. "Prinsip-prinsip Manajemen Keuangan”. Salemba Empat, 2013.

Husein. Umar. "Metode Penelitian Untuk Skripsi dan Tesis Bisnis”. PT. Rajagrafindo Persada, Jakarta, 2008.

Idroes. Ferry "Manajemen Risiko Perbankan: Pemahaman Pendekatan 3 Pilar Kesepakatan Base II Terkait Aplikasi Regulasi dan Pelaksanaannya di Indonesia”. PT. Rajagrafindo Persada, Jakarta, 2008.

“Manajemen Risiko 1". Edisi Pertama, Gramedia Pustaka Utama, Jakarta, 2016.

Ismail. "Manajemen Perbankan". Prenada Media Group, Jakarta, 2010.

J Fred Weston, Thomas E Copeland. "Manajemen Keuangan". Edisi 
Kedelapan, Binarupa Aksara

Publisher, Jakarta, 2009.

Kasmir. "Manajemen Perbankan". Rajagrafindo Persada, Jakarta, 2001.

"Pengantar Mananjemen Keuangan”. Edisi Pertama, Cetakan Kedua, Kencana Prenada Media Group, Jakarta, 2010.

"Analisis Laporan Keuangan".

Cetakan Kelima, Rajagrafindo

Persada, Jakarta, 2012.

"Analisis Laporan Keuangan".

Rajawali Persada, Jakarta, 2013.

"Bank dan Lembaga Keuangan Lainnya”. Edisi Revisi, PT. Rajagrafindo Persada, Jakarta, 2014. Kuncoro. Mudrajat. "Metode Kuantitatif Teori dan Aplikasi untuk Bisnis \& Ekonomi”. Edisi Keempat, UPP STIM YKPN, Yogyakarta, 2011.

Martono. "Bank dan Lembaga Keuangan Lainnya”. Ekonisia, Yogyakarta, 2002.

Muhammad. "Manajemen Bank Syariah". AMPYKPN, Yogyakarta, 2005.

Mulyono. Agus. "Manajemen”. Edisi Ketiga, BPFE, Yogyakarta, 2001.

Munawir. "Analisis Laporan Keuangan". Edisi Keempt, Liberty, Yogyakarata, 2010.

Ni Made Inten Uthami Putri Warsa dan I Ketut Mustanda. "Pengaruh CAR, LDR dan NPL Terhadap ROA Pada Sektor Perbankan Di Bursa Efek Indonesia”. Univesitas Udayana,
Bali, 2016.

Nyoman Triana Dewi dan I Gede Suparta Wisadha. "Pengaruh Kualitas Aktiva Produktif, CAR, Leverage dan IDR Pada Profitabilitas Bank”. Univesitas Udayana, Bali, 2015.

Prayudi. Arditya. "Pengaruh CAR, NPL, ROA dan NIM Terhadap LDR". Sragen, 2011.

Ponco, Budi. "Analisis Pengaruh CAR, NPL, BOPO, NIM dan LDR Terhadap ROA”. Universitas Diponogoro, Semarang, 2008.

Riyadi. Slamet. "Banking Assets and Liability Management”. Edisi Ketiga, FEUI, Jakarta, 2006.

Siamat. Dahlan. "Manajemen Lembaga Keuangan”. FEUI, Jakarta, 2001.

Suad Husnan, Enny Pudjiastuti. "Dasardasar Manajemen Keuangan”. Edisi Ketiga, Cetakan Pertama, UPP AMP YKPN, Yogyakarta, 2002.

Sugiyono. "Statistik Untuk Penelitian". Alfabeta, Bandung, 2006.

"Metode Penelitian Pendidikan". Cetakan Ketujuh, Alfabeta, Bandung, 2009.

Takarini. Nurjanti dan Ukki Hayudanto Putra. "Dampak Tingkat Kesehatan Bank Terhadap Perubahan Harga Saham Pada Perusahaan Perban kan Yang Go Public Di Bursa Efek Indonesia (BEI)". UPN Veteran Jatim, Surabaya, 2010 